\title{
Priority Communicable Disease Surveillance (PCDS) in Bangladesh
}

\author{
Mohammed A. Kalam* \\ Research, Siam Health Care, Dhaka, Bangladesh
}

\section{Objective}

Surveillance of priority communicable diseases started with a view to build up an early warning system for certain important public health important diseases in Bangladesh, namely: (1) Diarrheal disease (acute watery diarrhea and bloody dysentery); (2) Malaria; (3) Kala-azar; (4) Tuberculosis; (5) Leprosy; (6) Encephalitis; (7) Unknown diseases of public health concern

\section{Introduction}

Disease surveillance is an epidemiological practice by which the spread of disease is mentioned in order to establish patterns of progression. The main role of Priority Communicable Disease Surveillance (PCDS) is to predict, observe, and minimize the harm caused by outbreak, epidemic, and pandemic situations, as well as increase our knowledge to what factors might contribute to such circumstances. A key part of modern disease surveillance is the practice of disease case reporting.

\section{Methods}

Data for PCDS were collected by web based disease surveillance (WBDS) system since April 2009. Data were analyzed for eight diseases - acute watery diarrhea, bloody dysentery, encephalitis, kala-azar, leprosy, malaria severe, malaria uncomplicated, tuberculosis and unknown diseases - covering all divisions of Bangladesh for the year 2009, 2010 and 2011. The WBDS started from April 2009 and continues to date (table: 1 ).

Reporting takes place weekly and involves the Upazilas (sub-districts) of the entire country. Upazila Health \& Family Planning Officers and Civil Surgeon (CS) at district levels are responsible for conducting this surveillance locally.

Priority communicable diseases data were analyzed from all the reported Upazila in Bangladesh from January 2007 to July 2008.

We received at least one report from at least one Upazila from 61 districts out of 64 districts in 2007and from 59 districts up to July 2008. We did not get any report for even a week from Tangail in Dhaka division, Brahmanbaria in Chittagong division and Jhalokathi in Barisal division either in 2007 or up to July 2008. Moreover, we did not get any report from Bhola in Barisal division and Moulvibazar in Sylhet division in 2008.

\section{Results}

Acute watery diarrhea was the most reported priority communicable disease both in 2007 and up to July 2008. Bloody dysentery was the second common reported disease. Encephalitis was the least reported disease in both periods.

If we calculate disease data by monthly average, the highest (48,534/month) was in 2009 , and the lowest $(33,703 /$ month) was in 2011.

Monthly patient cases were 11,510 in Dhaka divisions (which is the highest) followed by Chittagong (10,586), Rajshahi $(8,909)$, Khulna $(7,116)$, Sylhet $(2,182)$, Barisal $(1,355)$, and Rangpur (999) the population and the number of Upazila are highest in Dhaka division. So the finding of highest cases in Dhaka division is plausible. (Table:2)

\section{Conclusions}

Our Priority Communicable Disease Surveillance System enables local public health authorities, hospitals, laboratories, and Directorate of Health Services to collaborate electronically as they perform disease reporting and surveillance activities across the country. The information compiled from this program is used for developing insights on health problems in the country.

Table:1, Results of PCDS

\begin{tabular}{|c|c|c|c|c|c|c|c|}
\hline No. Division & $\begin{array}{c}\text { Total No. of } \\
\text { Districts }\end{array}$ & Jan-Dec 2007 & $\begin{array}{c}\text { Upto July } \\
2008\end{array}$ & $\begin{array}{c}\text { Total No. of } \\
\text { Upazilas }\end{array}$ & Jan-Dec 2007 & $\begin{array}{c}\text { Up to July } \\
2008\end{array}$ \\
\hline & $\begin{array}{c}\text { Reported } \\
\text { Districts, } \\
\text { No.(\%) }\end{array}$ & $\begin{array}{c}\text { Reported } \\
\text { Districts, } \\
\text { No.(\%) }\end{array}$ & & $\begin{array}{c}\text { Reported } \\
\text { Upazilas, } \\
\text { No.(\%) }\end{array}$ & $\begin{array}{c}\text { Reported } \\
\text { Upazilas, } \\
\text { No.(\%) }\end{array}$ \\
\hline 1 & Dhaka & 17 & $16(94)$ & $16(94)$ & 119 & $55(46)$ & $52(44)$ \\
\hline 2 & Chittagong & 11 & $10(100)$ & $10(100)$ & 92 & $43(47)$ & $44(48)$ \\
\hline 3 & Rajshahi & 16 & $16(100)$ & $16(100)$ & 126 & $63(50)$ & $54(43)$ \\
\hline 4 & Khulna & 10 & $10(100)$ & $10(100)$ & 60 & $31(52)$ & $32(53)$ \\
\hline 5 & Barisal & 6 & $5(83)$ & $4(67)$ & 40 & $14(35)$ & $7(18)$ \\
\hline 6 & Sylhet & 4 & $4(100)$ & $3(75)$ & 36 & $9(25)$ & $6(17)$ \\
\hline & Total & 64 & $61(95)$ & $59(92)$ & 473 & $215(46)$ & $195(141)$ \\
\hline
\end{tabular}

\begin{tabular}{|c|c|c|c|c|}
\hline Division & 2009 & 2010 & 2011 & Per year \\
\hline Dhaka & 120,244 & 155,631 & 80,945 & 118,940 \\
\hline Chittagong & 105,200 & 134,826 & 88,169 & 109,398 \\
\hline Sylhet & 31,475 & 4,715 & 31,451 & 22,547 \\
\hline Barisal & 15,743 & 13,357 & 12,918 & 14,006 \\
\hline Rajshahi & 94,439 & 131,130 & 50,618 & 92,062 \\
\hline Khulna & 69,705 & 87,964 & 62,940 & 73,536 \\
\hline Rangpur" & & & 9,989 & 9,989 \\
\hline All division & 436,806 & 527,623 & 337,030 & 433,820 \\
\hline Per division & 62,401 & 75,375 & 48,147 & \\
\hline
\end{tabular}

Table: 2, Division and year-wise Patient Cases of Bangladesh (Apr. 09 to Sep 2011)

Note: Rangpur division was creates out of Rajshahi division from 2011

\section{Keywords}

Division; Disease; diarrhea

\section{References}

IEDCR. At the Front Lines of Public Health, Bangladesh 2006-2011

*Mohammed A. Kalam

E-mail: med_sociology_iedcr@yahoo.com 